\title{
MEASURING THE NATIONAL ZAKAT INDEX (NZI) ON ZAKAT PERFORMANCE IN BOGOR REGENCY
}

\author{
Ulfah Laelatul Hilmiyah ${ }^{1}$ \\ Irfan Syauqi Beik ${ }^{2}$ \\ Khonsa Tsabita ${ }^{3}$
}

\begin{abstract}
Poverty is the most crucial problem in many countries including Indonesia. As a predominantly Muslim countries, there are several Islamic instruments to combat poverty, such as zakat. It is an act of worship that combines economic, social, moral and religious components to improve the welfare of Muslims, as well as reducing poverty. Bogor Regency, a region in Indonesia, targeted 10 billion rupiah as its zakat collection for 2016. However, the actual zakat collection was only 5 billion rupiahs, which signals the ineffectiveness of zakat management from either collection, distribution, or utilization. The purpose of this research is to analyse zakat performance in BAZNAS (Badan Amil Zakat Nasional; National Board of Zakat) in Bogor Regency. Data were collected through interviews and questionnaires completed by 100 mustahik household in Bogor Regency. The National Zakat Index was used with a calculation method called the Multi-Stage Weighted Index. The findings indicate that the implementation of zakat performance in BAZNAS Bogor Regency is fairly good.
\end{abstract}

Keywords: National Zakat Index (NZI), Poverty, Zakat Performance.

JEL Classification: D64, Z12, Z18

Received : September 18, 2017

Revised : April 17, 2018

Accepted : May 3, 2018

1 Bachelor of Islamic Economics, Bogor Agricultural University (IPB), Indonesia, Email: khonsabita@gmail.com

2 Lecturer at Department of Islamic Economics, Bogor Agricultural University (IPB) and Director of Center of Strategic Studies (PUSKAS), The National Board of Zakat (BAZNAS) Indonesia, Email: HYPERLINK “mailto:irfan.beik@puskasbaznas.com" irfan.beik@puskasbaznas.com

3 Senior Researcher at Center of Strategic Studies (PUSKAS), The National Board of Zakat (BAZNAS). Corresponding author: khonsabita@gmail.com 
Zakat, the third pillar of Islam, is defined as the amount of wealth that Allah requires the owner to give to those who are entitled to receive it (Qardawi, 2011). Zakat is a proportion of wealth that must be deducted if it already fulfills the requirements. It must be distributed to the eight groups (ashnaf) that have been entitled to receive zakat as it is declared in the Quran Surah At-Tawbah verse 60: “

Zakat expenditures are only for the poor and for the needy and for those employed to collect [zakat] and for bringing hearts together [for Islam] and for freeing captives [or slaves] and for those in debt and for the cause of Allah and for the [stranded] traveleran obligation [imposed] by Allah. And Allah is Knowing and Wise".

Consistent with the verse, the strategic objectives of zakat are explicitly to eradicate poverty and improve the welfare of Muslims. The last decade has shown an extensive growth of the role of zakat institutions in eradicating poverty in Indonesia. Murniati (2014) stated that the poverty problem could be solved through zakat since it is an instrument of wealth transfer from muzakki (zakat donor) to mustahik (zakat receiver) (Hafidhuddin, 2002).

Being the country with the largest Muslim population, it is imperative for Indonesia to carefully evaluate zakat practice. Muslims who have reached the requirement to pay zakat must fulfill their zakat obligation. This creates huge potential of zakat in Indonesia. According to Firdaus et al. (2012), zakat potential in Indonesia reached 217 trillion rupiah or equivalent to 3.4 percent of Indonesia's GDP in 2010. This potential is even higher (reached 286 trillion rupiah) when it is generated by using an extrapolation method that takes into account GDP growth in previous years (BAZNAS, 2016). In this case, one of the regions in Indonesia with enormous potential of zakat collection is West Java Province.

Bogor Regency is the most populous region in West Java. The number of residents in Bogor Regency in 2016 was 5,459,668 people with Muslim population of 5,296,987 people or 97 percent of the total population (Central Bureau of Statistics, 2016). Considering the large proportion of Muslims in the region, Bogor Regency targeted its zakat collection to reach 10 billion rupiah annually. Nevertheless, the zakat funds collected in 2016 totaled only 5 billion rupiah (only five percent of the target). This gap shows the ineffectiveness of zakat practices (collection, distribution and utilization) in the region. Zakat procedures need to be further analyzed to discover a way to improve its management. Therefore, this paper attempts to measure and analyze the zakat performance in BAZNAS Bogor Regency using the National Zakat Index (NZI).

The NZI was created by the Center of Strategic Studies (PUSKAS) BAZNAS. This index is a composite index that was generated to measure national zakat development conditions. The NZI is divided into two dimensions: macro and micro dimensions. The macro dimension reflects how the role of government and society together contribute to build the zakat institution. The micro dimension comes from the institutional zakat perspective and the zakat receiver (mustahik) perspective.

This research paper is divided into five sections. Section 1 explores the background of the research, Section 2 delineates literatures review, Section 3 describes the methodology, Section 4 explains about general the result and analysis, and Section 5 concludes the discussion and provides recommendation. 


\section{LITERATURE REVIEW}

This section focuses on the theoretical framework explaining the National Zakat Index (NZI) as a standard measurement of zakat performance. A theoretical framework is constructed based on a review of previous studies on Islamic index, especially the zakat index. Generally, NZI is formulated as a result of the absence of an integrated and comprehensive index that can be used as a standard measurement of zakat performance.

Most of previous studies were created based on the partial dimension only, such as institutional aspect or zakat recipients only. Additionally, they mostly focused on case studies rather than on the macro scale. The presence of the zakat index that can be an indicator to evaluate zakat is urgently needed. Moreover, it will create a more measurable zakat management system to measuring capability, accountability, and transparency (Nurzaman et al., 2017)

The BAZNAS Centre of Strategic Studies, therefore, has started formulating an NZI as a measuring tool that is designed to evaluate the development of the zakat at the aggregate level (national and provincial). Using the SMART concept (specific, measurable, applicable, reliable, and timely [conducted in a periodical manner]), NZI is expected to become a measurement standard that can be applied by the regulator, by zakat institutions, and by the public to evaluate zakat development nationally (BAZNAS, 2016).

There have been extensive studies on zakat index. Yet, none of those studies employed the zakat index as a standard performance of zakat measurement nationally or globally. A study conducted by Abdullah et al. (2012) established indicators for evaluating the zakat performance. It also aimed to reduce poverty by distributing the zakat funds. This study formulated the Zakat Effectiveness Index (ZEIN), which consists of some variables: the proportion of the population below the poverty line, mustahik spending, and government spending on poverty alleviation. The results on the index calculation will be divided among three groups, called the relatively Less Needy if ZEIN < 0.50, Just Needy 0.75> ZEIN > 0.50 , and Very Needy ZEIN $>0.75$. Thus, this research provides a useful tool to measure the performance of all Muslim countries' provision of minimum basic needs through zakat.

Additional research focusing on the index was conducted by Ali and Hasan (2014). They studied on Maqashid Shari'ah-based development index, which is related to measurement of the poverty level. This study analyzed poverty from the basic need fulfillment based on Maqashid Shari'ah, which covers protection of wealth, protection of life, protection of intellect, protection of faith, and protection of posterity. Each of those dimensions has its own indicators to determine the index and level of poverty. Hence, this study can determine the level of each dimension that contributes to poverty.

Mohammed et al. (2015) conducted a study that has initiated the idea of operationalizing Al-Ghazali's five dimensions of maqashid from Ibn 'Ashur's theory of maqashid. This paper aims to develop a Maqashid-Based Performance Evaluation Model (MPEM), a model used to measure the performance of Islamic banks. The use of MPEM will also help policy makers, researchers, and regulators to construct rules and regulations that are in line with the maqashid. The elements 
of MPEM are: (1) Freedom of Faith; (2) Preservation of Human Dignity/Right; (3) Propagation of Scientific Thinking; (4) Care for Family; (5) Minimizing Income and Wealth Disparity; and (6) Well-being of Society.

In a contrast manner, Beik and Arsyianti (2015) constructed a CIBEST model, which is an Islamic poverty and prosperity indices. This index observes the level of poverty or mustahik's welfare, and also includes their spiritual level. Based on this study, both aspects are important measurements of a person's life balance, because it was revealed in the Qur'an and Sunnah that a man should not merely pursue success in the world, but also prepare for the hereafter. Furthermore, this model classifies a household into four categories according to the conditions and their capacity to meet the material and spiritual needs. These four categories are prosperous household (Quadrant-I), material poverty household (QuadrantII), spiritual poverty household (Quadrant-III), and absolute poverty household (Quadrant-IV).

CIBEST defined material poverty based on three approaches: a periodic survey on the needs of basic material; the standard of the poverty line set according to Central Bureau of Statistics (Badan Pusat Statistik; BPS) with some adjustment (calculating per household, not per capita); and setting the standard of nishab, which is a standard separator between muzakki and mustahik. The spiritual aspect, however, is based on the three groups of variables comprising of worship, family environment, and government policies (Beik and Arsyianti, 2016).

In the zakat index compiled by Noor et al. (2015), the measurement is categorized into four dimensions: input, process, output, and outcome. Each dimension has a variable that has its own weighted score, and thus the index score will be generated from the calculation of all those variables. The dimension of input consists of ashnaf, staff, and organization, followed by the process dimension; staff and management, output dimensions; types of programs, types of distribution, and the distribution ratio, the dimensions of outcome; and ashnaf upgraded, public perception, and governance. Each variable has its own weight, and the result after calculation of all the variables will produce the zakat index in which the range of score is $0-100$ percent.

Diana et al. (2017) assess and evaluate the performance of zakat practices in East Lampung Regency. This study applied the NZI, resulting in an NZI score of 0.38 (less good category). This score is derived from two dimensions: macro and micro dimensions. In the macro dimension, the zakat condition in East Lampung Regency is in the "not good" condition, with a score of 0.05. Meanwhile, in the micro dimension, it is in the good category, with an index value of 0.60 . The summary of previous studies are in Table 1. 
Table 1. Summary of the Previous Studies

\begin{tabular}{|c|c|c|c|c|}
\hline No & Index & Description & Variable & Author \\
\hline 1 & $\begin{array}{l}\text { Zakat Effectiveness } \\
\text { Index (ZEIN) }\end{array}$ & $\begin{array}{l}\text { This paper measured the } \\
\text { effectivity of government } \\
\text { expenditures on poverty } \\
\text { alleviation by the amount } \\
\text { of zakat. }\end{array}$ & $\begin{array}{l}\text { 1. Number of recipients } \\
\text { 2. Expenditure of } \\
\text { recipients } \\
\text { 3. Government spending } \\
\text { on poverty alleviation }\end{array}$ & $\begin{array}{l}\text { Abdullah et } \\
\text { al. (2012) }\end{array}$ \\
\hline 2 & $\begin{array}{l}\text { Maqashid al Shariah } \\
\text { based Development } \\
\text { Index }\end{array}$ & $\begin{array}{l}\text { This paper scrutinized } \\
\text { the socio-economic } \\
\text { development which is } \\
\text { in line with Maqashid al } \\
\text { Shariah. }\end{array}$ & $\begin{array}{l}\text { 1. Wealth protection } \\
\text { 2. Life protection } \\
\text { 3. Intellect protection } \\
\text { 4. Faith protection } \\
\text { 5. Posterity protection }\end{array}$ & $\begin{array}{l}\text { Ali and } \\
\text { Hasan (2014) }\end{array}$ \\
\hline 3 & $\begin{array}{l}\text { Maqashid based } \\
\text { Performance } \\
\text { Evaluation Model }\end{array}$ & $\begin{array}{l}\text { This paper examined the } \\
\text { performance of Islamic } \\
\text { banks based on Maqashid al } \\
\text { Shariah. }\end{array}$ & $\begin{array}{l}\text { 1. Freedom of faith } \\
\text { 2. Preservation of human } \\
\text { right } \\
\text { 3. Propagation of scientific } \\
\text { thinking } \\
\text { 4. Care for family } \\
\text { 5. Minimizing income and } \\
\text { wealth disparity } \\
\text { 6. Well-being of society }\end{array}$ & $\begin{array}{l}\text { Mohammed } \\
\text { et al. (2015) }\end{array}$ \\
\hline 4 & Zakat Index (ZIx) & $\begin{array}{l}\text { This paper assessed } \\
\text { the multidimensional } \\
\text { performance of zakat } \\
\text { organizations. }\end{array}$ & $\begin{array}{l}\text { 1. Input } \\
\text { - Ashnaf } \\
\text { - Staff organization } \\
\text { 2. Process } \\
\text { - Staff } \\
\text { - Management } \\
\text { 3. Output } \\
\text { - Types of program } \\
\text { - Types of distribution } \\
\text { 4. Outcome } \\
\text { - Ashnaf upgraded } \\
\text { - Public perception } \\
\text { - Governance }\end{array}$ & $\begin{array}{l}\text { Noor et al. } \\
\text { (2015) }\end{array}$ \\
\hline 5 & CIBEST Index & $\begin{array}{l}\text { This paper analyzed the } \\
\text { impact of zakat on poverty } \\
\text { and welfare which includes } \\
\text { four indices: welfare index, } \\
\text { material poverty index, } \\
\text { spiritual poverty index, and } \\
\text { absolute poverty index. }\end{array}$ & $\begin{array}{l}\text { 1. } \quad \text { Material Value } \\
\text { - } \quad \text { Income } \\
\text { 2. Spiritual Value } \\
\text { - } \quad \text { Comprising of worship } \\
\text { - } \quad \text { Family environment } \\
\text { - } \quad \text { Government policies }\end{array}$ & $\begin{array}{l}\text { Beik and } \\
\text { Arsyianti } \\
(2016)\end{array}$ \\
\hline 6 & $\begin{array}{l}\text { National Zakat } \\
\text { Index (NZI) }\end{array}$ & $\begin{array}{l}\text { This paper measured the } \\
\text { national zakat index (NZI) } \\
\text { score in East Lampung } \\
\text { Regency. The NZI score is } \\
0.38 \text { which puts it into less } \\
\text { good category for its zakat } \\
\text { performance. }\end{array}$ & $\begin{array}{l}\text { 1. Macro dimension } \\
\text { - } \text { Regulation } \\
\text { - Government budget } \\
\text { al.location } \\
\text { - Database of official } \\
\text { zakat institutions, } \\
\text { muzakki, and } \\
\text { mustahik } \\
\text { 2. Micro dimension } \\
\text { - Institution } \\
\text { - } \text { Zakat impact }\end{array}$ & $\begin{array}{l}\text { Diana et al. } \\
\text { (2017) }\end{array}$ \\
\hline
\end{tabular}




\section{METHODOLOGY}

\subsection{Data}

This research utilizes both primary and secondary data. The primary data was acquired through a questionnaire survey and interview. The mustahik of BAZNAS and officers of BAZNAS Bogor Regency were asked to complete the questionnaire survey and answer interview questions. Meanwhile, the secondary data was obtained from a literature study including books, journals, articles, and relevant documents from the Central Bureau of Statistics and BAZNAS Bogor Regency.

This research applies purposive sampling by choosing the respondents with pre-determined characteristics. The respondents consisted of 100 household mustahik who received zakat from the BAZNAS Bogor Regency in 2016. All the mustahiks are from the 'Mustahik Service' program in the BAZNAS Bogor Regency.

\subsection{Data Analysis Methods}

\section{a. National Zakat Index Analysis}

This research used the NZI as its method of analysis. The NZI was formulated by the Center of Strategic Studies (PUSKAS) of BAZNAS. This index is a composite index that was built to measure the condition of national zakat development (Nurzaman et al.., 2017). The NZI is divided into two dimensions: macro and micro dimensions. The macro dimension reflects on how the composite roles of the government and society contribute to build the zakat institution. This dimension has three indicators, called regulation, government budget allocation (APBN), and database of zakat institutions. Except for regulation and government budget allocation, the indicator of the zakat institution database was subdivided into three variables: the number of official zakat institutions, individual muzakki, and enterprise muzakki.

The micro dimension has two indicators: performance of the zakat institution and the zakat impact on the mustahik. Performance indicators of the zakat institution were then described using more detailed variables that measure the performance of the institution from the aspect of collection, management, distribution, and reporting. Zakat impact indicators consist of five variables that view the impact from economic, spiritual, education, health, and independency viewpoints. Thus, the NZI components are illustrated in Figure 1 and the weighted score for each NZI component can be observed in Table 2. 


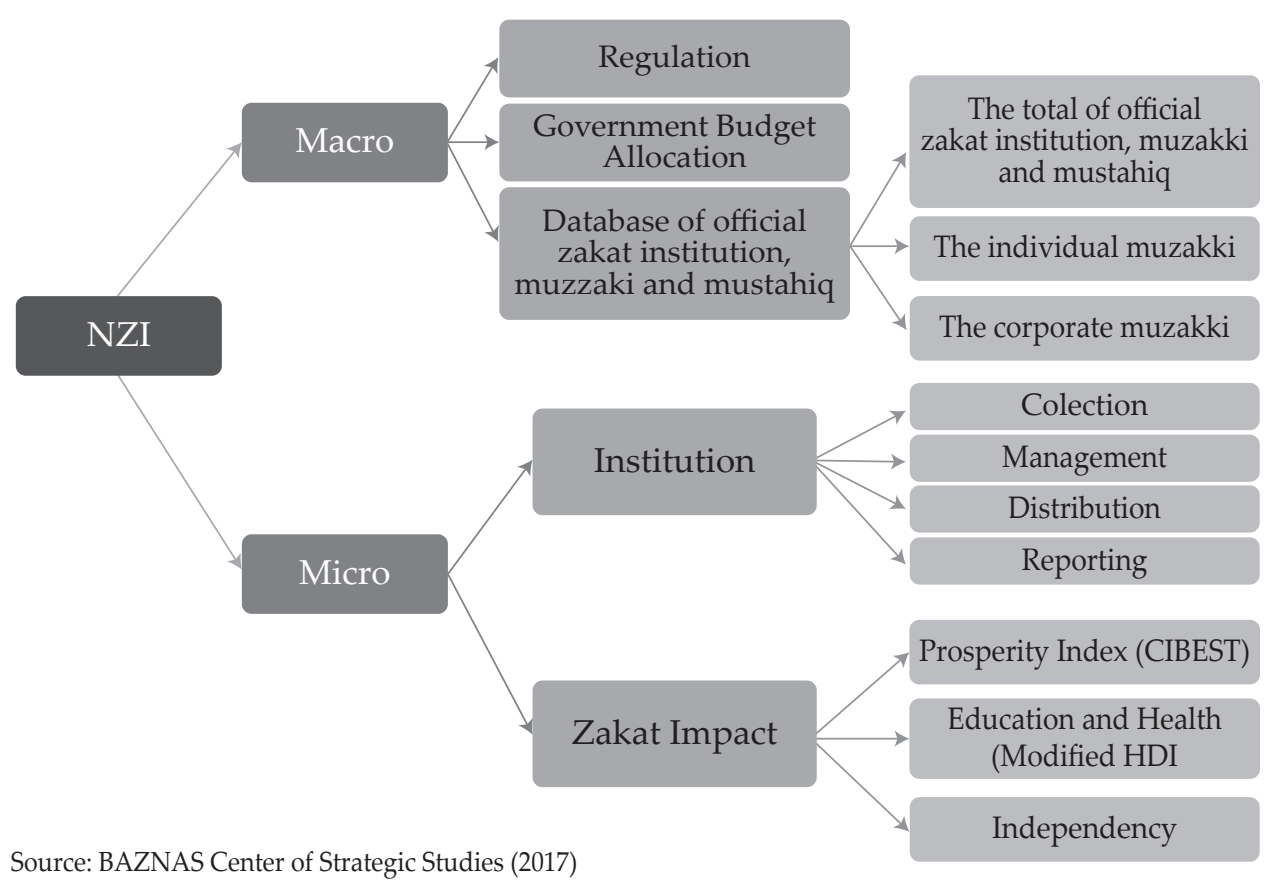

Figure 1. NZI Components

Table 2. Weighted Score of NZI Components

\begin{tabular}{|c|c|c|c|c|c|}
\hline Dimension & $\begin{array}{l}\text { Weighted } \\
\text { Score }\end{array}$ & Indicator & $\begin{array}{l}\text { Weighted } \\
\text { Score }\end{array}$ & Variable & $\begin{array}{c}\text { Weighted } \\
\text { Score }\end{array}$ \\
\hline Macro & 0.40 & $\begin{array}{c}\text { Regulation }\left(X_{11}\right) \\
\text { Government } \\
\text { Budget }\left(X_{12}\right) \\
\text { Zakat } \\
\text { Institution } \\
\text { Database }\left(X_{13}\right)\end{array}$ & $\begin{array}{l}0.30 \\
0.40 \\
0.30\end{array}$ & $\begin{array}{c}\text { Regulation } \\
\\
\text { Government Budget } \\
\text { Number of official zakat } \\
\text { institution }\left(X_{131}\right) \\
\text { Individual Muzakki Ratio } \\
\left(X_{132}\right) \\
\text { Enterprise Muzakki Ratio } \\
\left(X_{133}\right)\end{array}$ & $\begin{array}{l}1.00 \\
1.00 \\
0.33 \\
0.33 \\
\\
0.33\end{array}$ \\
\hline $\operatorname{Micro}\left(X_{1}\right)$ & 0.60 & $\begin{array}{c}\text { Institutional }\left(X_{21}\right) \\
\text { Impact of Zakat } \\
\left(X_{22}\right)\end{array}$ & $\begin{array}{l}0.40 \\
0.60\end{array}$ & $\begin{array}{c}\text { Collection }\left(X_{211}\right) \\
\text { Management }\left(X_{212}\right) \\
\text { Distribution }\left(X_{213}\right) \\
\text { Reporting }\left(X_{214}\right) \\
\text { Material and Spiritual } \\
\left(\text { CIBEST) }\left(X_{221}\right)\right. \\
\text { Education and Health } \\
\text { (HDI Modified) }\left(X_{222}\right) \\
\text { Independency }\left(X_{223}\right)\end{array}$ & $\begin{array}{l}0.30 \\
0.20 \\
0.30 \\
0.20 \\
\\
0.40 \\
\\
\\
0.40 \\
0.20\end{array}$ \\
\hline
\end{tabular}


The NZI formulation model was divided systematically into five steps. The first step was to create the Likert scale score with a range of 1 to 5 , where the score of 1 describes the worst condition, and 5 describes an excellent condition. The second step was to calculate the index of each variable. The formula for calculating the index on each variable is as follows:

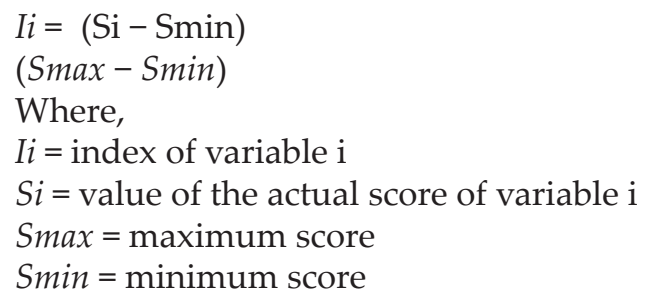

The value of the index lies within the range of 0.00-1.00. This means the lower index values indicate a poor performance of the national zakat, and higher index values indicate a better zakat condition. The NZI index score is divided into five categories: $0.00-0.20$ for the not good category; $0.21-0.40$ for the less good category; $0.41-0.60$ for the good category; $0.61-0.80$ for the good category; and $0.81-1.00$ for very good category.

The third step was to multiply the index obtained using each variable by the respective weight to derive the index of the indicators. Two indicators are regulation and government budgets, and these are not specified by more detailed variables, so they do not require certain calculations at this stage. However, three other indicators, which break down into several variables using the formula below:

$X_{13}=0.33 X_{131}+0.33 X_{132}+0.33 X_{133}$

where,

$X_{13}$ : indicator index of database of zakat institution

$X_{131}$ : variable index of total number of official zakat institutions, registered muzakki and mustahik

$X_{132}$ : variable index of individual muzakki ratio against the number of households

$X_{133}$ : variable index of enterprise muzakki ratio against the total number of enterprises

$X_{21}=0.30 X_{211}+0.20 X_{212}+0.30 X_{213}+0.20 X_{214}$

where,

$X_{21}$ : indicator index of institution

$X_{211}$ : variable index of collection

$X_{212}$ : variable index of management

$X_{213}$ : variable index of distribution

$X_{214}$ : variable index of reporting

$X_{22}=0.40 X_{221}+0.40 X_{222}+0.20 X_{223}$ 
where,

$X_{22}$ : indicator index of zakat impact

$X_{221}$ : variable index of material and spiritual impact (based on CIBEST Model)

$\mathrm{X}_{222}$ : variable index of education and health (Modified Human Development Index (HDI))

$\mathrm{X}_{223}$ : variable index of independence

The fourth step was to multiply the index obtained for each indicator by the respective weight to obtain the index of the macro and micro dimensions.

$\mathrm{X}_{1}=0.30 \mathrm{X}_{11}+0.40 \mathrm{X}_{12}+0.30 \mathrm{X}_{13}$

where,

$X_{1}$ : index of macro dimension

$X_{11}$ : indicator index of regulation

$X_{12}$ : indicator index of government budget support

$\mathrm{X}_{13}$ : indicator index of database of zakat institutions

$\mathrm{X}_{2}=0.40 \mathrm{X}_{21}+0.60 \mathrm{X}_{22}$

where,

$X_{2}$ : index of micro dimension

$X_{21}$ : indicator index of institution

$X_{22}$ : indicator index of zakat impact

The last step was to multiply the index obtained for each dimension by the respective weight to obtain a NZI, which is:

$\mathrm{NZI}=0.40 \mathrm{X}_{1}+0.60 \mathrm{X}_{2}$

where,

NZI : National Zakat Index

$\mathrm{X}_{1}$ : index of macro dimension

$X_{2}$ : index of micro dimension

\section{b. CIBEST Analysis}

The CIBEST model combines the quadrants of basic human needs, including both material and spiritual aspects (CIBEST quadrants and CIBEST indices). The CIBEST quadrant is based on the conception and typology of the household. It uses the household as a unit of analysis, following the concept from the National Coordinating Agency for Family Planning Program (Badan Koordinasi Keluarga Berencana Nasional; BKKBN). This model divides household into four possible situations depend on their ability to fulfil material and spiritual needs (Beik and Arsyianti, 2016).

The first is as the prosperous household, which is able to fulfil both material and spiritual needs completely. Second is known as the household that lives in material poverty because it fulfils spiritual needs only. The opposite of the second situation is the third is the household that lives under spiritual poverty because it is only able to fulfil the material needs. The fourth is the worst situation of the household in which both material and spiritual needs are unable to be fulfilled. 
This situation is called as absolute poverty. Derived from the CIBEST quadrants, the CIBEST index is formulated and divided into four indices, called the welfare index (Quadrant I), material poverty index (Quadrant II), spiritual poverty index (Quadrant III), and absolute poverty index (Quadrant IV). The CIBEST quadrants are in Figure 2.

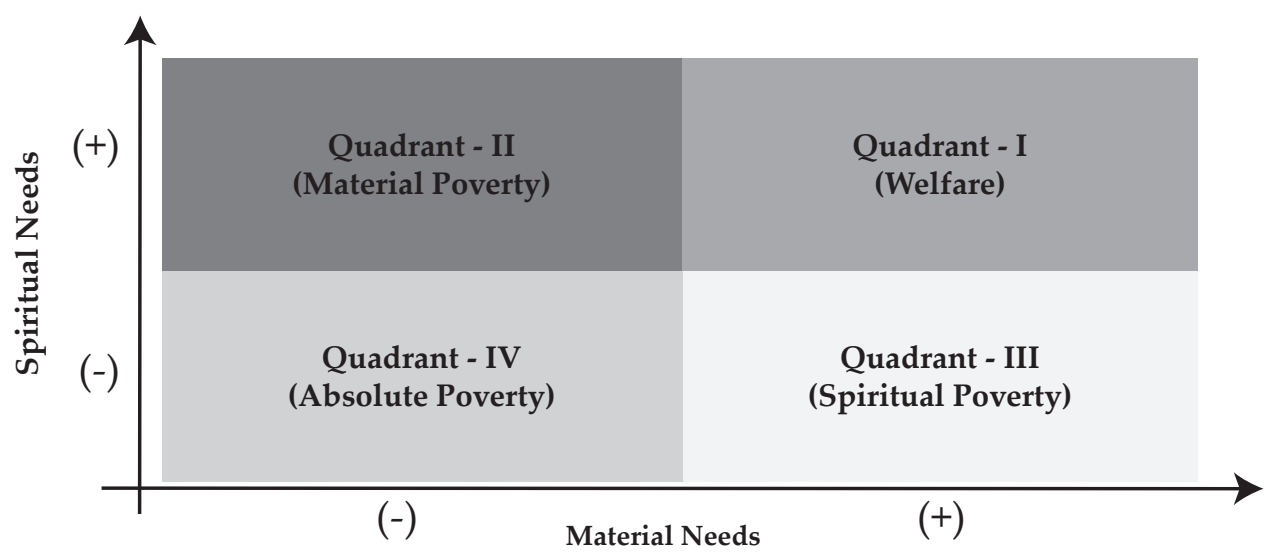

Figure 2. CIBEST Quadrant

\section{RESULT AND ANALYSIS}

The NZI results are derived from two dimensions: macro and micro dimensions. In the macro dimension, there are three indicators: regulation, local government budget support to BAZNAS Bogor Regency, and the database of zakat institutions in Bogor Regency. First, from the regulation indicator, the Bogor Regency did not have a local regulation for zakat. Thus, for this indicator, Bogor Regency has an index score of zero (0).

Second, from the local government budget (APBD) allocation, the BAZNAS Bogor Regency gets its support for the zakat activities. The amount of APBD was 1 billion rupiah in 2016. The operational cost of the BAZNAS Bogor Regency was also included in the APBD that came from Bogor Regional government grant. Thus, for the APBD allocation fund, the Bogor Regency has an index score of one.

Third is the zakat institution database. It consists of three variables: (1) the number of official zakat institutions, the zakat donor (muzakki), and the zakat receiver (mustahik); (2) the ratio of individual muzakki; and (3) the ratio of corporate muzakki. The BAZNAS Bogor Regency did not have a database of official zakat institutions, muzakki, and mustahik. Thus, the index value for those variables is 0 . The effectiveness collecting and using zakat funds is highly dependent on the completeness of the database, particularly with regard to the number of individual muzakki and mustahik registered.

For the ratio of individual muzakki is known from the number of individual muzakki who has Zakat ID number (Nomor Pokok Wajib Zakat) in the BAZNAS Bogor Regency is $0.003 \%$ (i.e. less than one percent). This indicates that the index value of the ratio of individual muzakki is zero. The index value of the ratio of 
corporate muzakki is also zero because there is not yet a corporation that pays zakat in the BAZNAS Bogor Regency. Therefore, the zakat institution database in Bogor Regency resulted in an index score of zero. Details of the macro dimension score are illustrated in Table 3.

Table 3. Macro Dimension Index Score

\begin{tabular}{clc}
\hline No & \multicolumn{1}{c}{ Indicator } & Index Score \\
\hline 1 & Regulation $\left(\mathrm{X}_{11}\right)$ & 0 \\
\hline 2 & Local government budget support $\left(\mathrm{X}_{12}\right)$ & 1 \\
\hline 3 & Database of zakat institutions in East Lampung $\left(\mathrm{X}_{13}\right)$ & 0 \\
\hline Index score of macro dimension in Bogor Regency & \\
$=0.30\left(\mathrm{X}_{11}\right)+0.40\left(\mathrm{X}_{12}\right)+0.30\left(\mathrm{X}_{13}\right)$ & \\
$=0.30(0)+0.40(1)+0.30(0)$ & \\
$=0.4$ &
\end{tabular}

Source: Primary data (2017)

The next dimension is the micro dimension, which consists of two indicators: an institutional indicator and a zakat impact indicator. The institutional indicator is related to the performance of the BAZNAS Bogor Regency in managing zakat. This indicator is divided into four variables: zakat collection, management, distribution, and reporting. The zakat impact indicator is associated with the impact of zakat on mustahik as a zakat recipient. The zakat impact indicator consists of material and spiritual welfare (CIBEST index), education and health (Modified Human Development Index [HDI]), and the Independency index.

The first variable of the institutional indicator is the zakat collection. This variable is shown by the growth of the zakat fund collected by the zakat institutions. In the Bogor Regency, the zakat collection raised more than 20 percent (82.9 percent), so this variable has a score of 5 . The second variable, zakat management, has a score of four because the BAZNAS Bogor Regency already has a Standard Operating Procedure (SOP) for zakat management, a strategic plan, and an annual work program. This means that the performance in zakat management is in the good category.

The third variable is zakat distribution. The BAZNAS Bogor Regency has an allocation-to-collection ratio (ACR) score of 66.6 percent. The zakat distribution to the poor was mostly made by providing education, health, and business capital. For distribution speed on social and economic programs, it was successfully distributed in one year. Additionally, the zakat fund allocated to the dakwah program was five percent. Thus, the index score in the zakat distribution variable is 0.5 , which places it into the fairly good category.

Zakat reporting is the last variable, and it is different from the previous variable, having an index score of 0.25 . This is because the financial statements of the BAZNAS Bogor Regency are only internally audited. This means that the reporting variable is in the less good category. Thus, the institutional indicator of the BAZNAS Bogor Regency has a good performance, with a score of 0.65 . 
However, the CIBEST index results showed good material and spiritual welfare for the mustahik, with an index score of 0.75 . For education and health, the index score was 0.5 (using a modified HDI). This means that education and health of the mustahik in Bogor Regency is fairly good. The same value (0.5) is obtained for the independency index. This indicates that the level of mustahik self-sufficiency is in the good category.

The combined results of the three-zakat impact variables (CIBEST index, modified HDI, independency index) creates the zakat impact indicator with a score of 0.60. Therefore, the zakat impact indicator for mustahik in the Bogor Regency is in the fairly good category. Thus, the institutional indicator and zakat impact indicator index scores resulted a micro dimension index score of 0.62 . This shows that in the micro dimension, the zakat condition in Bogor Regency, especially for the performance of the BAZNAS Bogor Regency, is in the good category. The details of the micro dimension index score are in Table 4.

Table 4. Micro Dimension Index Score

\begin{tabular}{ccc}
\hline No & Indicator & Index Score \\
\hline 1 & Institutional $\left(\mathrm{X}_{21}\right)$ & 0.65 \\
\hline 2 & Zakat impact $\left(\mathrm{X}_{22}\right)$ & 0.60 \\
\hline Index score of micro dimension in East Lampung Regency & \\
$=0.40(\mathrm{X} 21)+0.60(\mathrm{X} 22)$ & \\
$=0.40(0.65)+0.60(0.60)$ & \\
$=0.62$ &
\end{tabular}

Source: Primary data (2017)

Based on the NZI measurement, zakat in Bogor Regency is in a fairly good category, with an index value of 0.53 . A summary of the NZI score is presented in Table 5.

Table 5. Summary of the National Zakat Index in Bogor Regency

\begin{tabular}{clc}
\hline No & Dimension & Index Score \\
\hline 1 & Macro & 0.40 \\
\hline $2 \quad$ Micro & 0.62 \\
\hline NZI score in Bogor Regency & \\
$=0.40(\mathrm{X} 1)+0.60(\mathrm{X} 2)$ & \\
$=0.40(0.40)+0.60(0.62)$ & \\
$=0.53$ & & \\
\hline
\end{tabular}

Source: Primary data (2017) 


\section{CONCLUSIONS AND RECOMMENDATIONS}

\subsection{Conclusions}

Based on the NZI measurement, the zakat condition in Bogor Regency is generally in the fairly good category, with an index value of 0.53 . On the macro dimension, zakat in Bogor Regency is in the less good condition, with a score of 0.40. This result is based on three indicators: regulation is zero (0), local government budget allocation is one (1), and database for zakat institutions is zero (0).

In the micro dimension, there are two indicators: institutional indicator (0.65) and zakat impact (0.60). The zakat condition in the Bogor Regency is represented by the performance of the BAZNAS Bogor Regency, and is in the good category, with an index score of 0.62 . Thus, both macro and micro dimensions contribute an equal portion to the NZI, which resulted an index score of 0.53 in the case of Bogor Regency.

\subsection{Recommendations}

A step that can be taken to improve the zakat condition in the Bogor Regency is strengthening government regulations regarding the Regional Regulation for zakat practice. In addition, the BAZNAS Bogor Regency needs to update the database of zakat institutions; the number of official zakat institutions, mustahik, and muzakki; and the ratio of individual muzakki and corporate muzakki.

The distribution of zakat through capital assistance for business provides a good impact on mustahik welfare and creates economic independence for mustahik. In addition, BAZNAS should be consistent to determine the standards or criteria of mustahik who are eligible to receive zakat and provide guidance to the mustahik household to increase economic and spiritual independence for fulfilling their primary needs.

\section{REFERENCES}

Abd Halim Mohd Noor, Mohamed Saladin Abdul Rasool, Rozman Md. Yusof, Siti Mariam Ali, \& Rashidah Abdul Rahman. (2015). Efficiency of Islamic Institutions: Empirical Evidence of Zakat Organizations' Performance in Malaysia. Journal of Economics, Business and Management, 3(2), pp. 282-286. http://doi.org/10.7763/JOEBM.2015.V3.195

Abdullah, N., Mahyudi, M., Yusop, M., \& Omar, C. (2012). a Technical Note on the Derivation of Zakat Effectiveness Index ( Zein ). International Journal of Economics, Management And Accounting, 1(1), pp. 75-86.

Ali, S. S., \& Hasan, H. (2014). IRTI Working Paper Series Towards a Maqashid alShariah based Development Index. Islamic Research and Training Institute, 18, pp. 1-22.

BAZNAS Center of Strategic Studies. (2016). Retrieved from www.puskasbaznas. com:http://puskasbaznas.com/outlook/indonesia-zakat-outlook-2017/69outlook-zakat-indonesia-2017-english

BAZNAS Center of Strategic Studies. (2016). Retrieved from www.puskasbaznas. com: http://puskasbaznas.com/national-zakat-index/nzi/download/72-nzi-2 
Beik, I. S., \& Arsyianti, L. D. (2015). Construction of Cibest Model As Measurement of Poverty and Welfare Indices From Islamic Perspective. Al-Iqtishad: Journal of Islamic Economics, 7(1), 87-104. http://doi.org/10.15408/ijies.v7i1.1361

Beik, I. S., \& Arsyianti, L. D. (2016). Measuring Zakat Impact on Poverty and Welfare Using CIBEST Model. Journal of Islamic Monetary Economics and Finance, 1(2), pp. 141-160.

Beik, I. S., \& Arsyianti, L. (2016). Ekonomi Pembangunan Syariah. Jakarta: Rajawali Pers.

Central Bureau of Statistics. (2016). Bogor Regency in Numbers. Bogor Regency: Central Bureau of Statistics.

Diana, Beik, I. S., \& Tsabita, K. (2017). Performance Analysis of Zakat Practices in East Lampung Regency using National Zakat Index ( NZI ), (August), 1-12.

Firdaus, M., Beik, I. S., Irawan, T., \& Juanda, B. (2012). Economic estimation and determinations of Zakat potential in Indonesia. IRTI Working Paper Series, WP 1433-07(August). Retrieved from http://www.isdb.org/irj/go/km/ docs/documents/IDBDevelopments/Internet/English/IRTI/CM/downloads/ Working Paper Series/WP-1433-07.pdf

Hafidhuddin, D. (2002). Zakat dalam Perekonomian Modern. Jakarta: Gema Insani.

Mohammed, M. O., Tarique, K., \& Islam, R. (2015). Measuring the performance of Islamic banks using maqāṣid -based model. Intelectual Discourse, 4878 (Special Issue (2015), pp. 401-424.

Murniati, R. (2014). The Role of Zakat on Human Development (Case of Zakat Utilization Program in BAZ Bogor City) [thesis]. Bogor: Bogor Agricultural University (IPB).

Nurzaman, M. S., Hendharto, R. G., Annisa, N., Khairunnajah, Noviyanti, \& Choirin, M. (2017). National Zakat Index: Framework and Methodology. Puskas Working Paper Series, (January), 1-22.

Qardawi, Y. (2011). Hukum Zakat. Jakarta: Litera Antarnusa. 